\title{
Soil microbial diversity drives the priming effect along climate gradients: a case study in Madagascar
}

\author{
Kanto Razanamalala ${ }^{1}$, Tantely Razafimbelo ${ }^{1}$, Pierre-Alain Maron ${ }^{2}$, Lionel Ranjard ${ }^{2}$, \\ Nicolas Chemidlin ${ }^{2}$, Mélanie Lelièvre ${ }^{3}$, Samuel Dequiedt ${ }^{3}$, Volaniaina H Ramaroson ${ }^{1}$, \\ Claire Marsden ${ }^{4}$, Thierry Becquer ${ }^{5}$, Jean Trap ${ }^{5,6}$, Eric Blanchartt,6 and Laetitia Bernard ${ }^{5,6}$ \\ ${ }^{1}$ Laboratoire des Radio-Isotopes, Antananarivo, Madagascar; ${ }^{2}$ INRA, UMR1347 Agroécologie, Dijon, France; \\ ${ }^{3}$ INRA, Plateforme GenoSol, UMR1347 Agroécologie, Dijon, France; ${ }^{4}$ Supagro, UMR 210 Eco\&Sols, \\ Montpellier Cedex 1, France; ${ }^{5}$ IRD, UMR 210 Eco\&Sols, Montpellier Cedex 1, France and ${ }^{6}$ IRD, UMR 210 \\ Eco\&Sols, Laboratoire des Radio-Isotopes, Antananarivo, Madagascar
}

\begin{abstract}
The priming effect in soil is proposed to be generated by two distinct mechanisms: 'stoichiometric decomposition' and/or 'nutrient mining' theories. Each mechanism has its own dynamics, involves its own microbial actors, and targets different soil organic matter (SOM) pools. The present study aims to evaluate how climatic parameters drive the intensity of each priming effect generation mechanism via the modification of soil microbial and physicochemical properties. Soils were sampled in the center of Madagascar, along climatic gradients designed to distinguish temperature from rainfall effects. Abiotic and biotic soil descriptors were characterized including bacterial and fungal phylogenetic composition. Potential organic matter mineralization and PE were assessed 7 and 42 days after the beginning of incubation with ${ }^{13} \mathrm{C}$-enriched wheat straw. Both priming mechanisms were mainly driven by the mean annual temperature but in opposite directions. The priming effect generated by stoichiometric decomposition was fostered under colder climates, because of soil enrichment in less developed organic matter, as well as in fast-growing populations. Conversely, the priming effect generated by nutrient mining was enhanced under warmer climates, probably because of the lack of competition between slow-growing populations mining SOM and fast-growing populations for the energy-rich residue entering the soil. Our study leads to hypotheses about the consequences of climate change on both PE generation mechanisms and associated consequences on soil carbon sequestration.
\end{abstract}

The ISME Journal (2018) 12, 451-462; doi:10.1038/ismej.2017.178; published online 17 October 2017

\section{Introduction}

Priming effect is an increase in soil organic matter mineralization by microorganisms following fresh organic matter (FOM) input (Bingeman et al., 1953; Kuzyakov et al., 2000). After more than two decades of increasing research effort, PE-generating mechanisms, determinants and actors still need to be elucidated (Fontaine et al., 2003; Bernard et al., 2007, 2009, 2012; Pascault et al., 2013; Chen et al., 2014). Based on a literature review, Fontaine et al. (2003) proposed that PE can be generated by two different mechanisms: (1) indirectly via collateral damage exerted on soil organic matter (SOM) by extracellular enzymes released by FOM feeders, and (2) directly via the co-metabolism of energy-rich FOM catabolites by SOM feeders who mine SOM for nutrients. Recently Chen et al. (2014), used the denomination of 'stoichiometric

Correspondence: L Bernard, UMR 210 Eco\&Sols, 2 place Viala Bt12, Montpellier Cedex 1, F-34060, France.

E-mail: laetitia.bernard@ird.fr

Received 10 May 2017; revised 7 September 2017; accepted 14 September 2017; published online 17 October 2017 decomposition theory' and 'nutrient mining theory' for each mechanism respectively. These authors showed that the first process is favored by high nitrogen concentration while the second takes place in case of nitrogen depletion. Therefore, when fresh carbon inputs are not accompanied by nutrient inputs, $\mathrm{PE}$ should first be generated by stoichiometric decomposition, followed by nutrient mining after exhaustion of available nutrients in the soil solution. Other authors have shown that during PE generation, early $\mathrm{PE}$ corresponded to the mineralization of young, labile $\mathrm{SOM}$ by fast-growing microbes whereas late $\mathrm{PE}$ targeted old SOM and involved slow-growing populations (Blagodatskaya et al., 2014; Derrien et al., 2014). As a consequence, PE generated by stoichiometric decomposition should result from the activity of faster-growing microbes than PE generated by nutrient mining (Fontaine et al., 2003; Chen et al., 2014). Using the coupling of isotopic and molecular approaches, a small number of studies have identified phylogenetic groups involved in the mineralization of wheat residues and potentially involved in the different PE processes at different decomposition stages (Bernard 
et al., 2007; Pascault et al., 2013). However, except for the soil nitrogen status, so far no other determinant of PE-generating processes is known.

The PE has been suspected to increase SOM mineralization in the context of global warming via the potential increase in labile carbon (C) inputs by plants to the soil in response to $\mathrm{CO}_{2}$ elevation (Heimann and Reichstein, 2008). However, it is not known whether temperature elevation (or rainfall variation) will be able to drive $\mathrm{PE}$ through the selection of different microbial guilds and/or the modification of the metabolism of the populations. This question is crucial for soil carbon sequestration, because if $\mathrm{PE}$ generated by nutrient mining leads to stable SOM depletion, PE generated by stoichiometric decomposition can be considered as a stimulation of the decomposition of young SOM and therefore a stimulation of the humification route.

The objective of this study was to determine how climatic parameters drive the capacity of microbial communities to mineralize organic matters and generate $\mathrm{PE}$, through one or another previously described mechanism, in Ferralsols across the centre of Madagascar. The rapid climate changes likely to occur in the tropics (Neelin et al., 2006), and the necessity for soils to sequester carbon and recycle nutrients from SOM for plant growth justify the need to deepen the understanding of the drivers and microbes involved in the generation of $\mathrm{PE}$ in the tropics. Madagascar is a highly relevant region to study these aspects due to the existence of crossed gradients of temperature and rainfall on the same soils (Ferralsols which account for 750 million ha of world-wide tropical areas and which are strongly nutrient-depleted) and with the same vegetation type (natural savannas locally called 'Bozaka'). Climatic gradients are useful to project the long-term response of microbial communities and $\mathrm{C}$ turnover under a situation of increasing temperature or rainfall, that are particularly difficult to set up in developing countries. Soil samples were collected under natural herbaceous savannas along several gradients allowing to separate the effects of mean annual temperature (MAT) and mean annual precipitation (MAP). Soils were first characterized on the basis of the most important biotic and abiotic descriptors: microbial biomass, diversity and composition, soil texture, mineralogy, $\mathrm{pH}$, water content, cationic exchange capacity, bulk density, total C, N, P contents, and available $\mathrm{N}$ and $\mathrm{P}$ contents. They were further incubated for 42 days to assess their capacity to mineralize wheat straw and SOM and to generate PE through both previously described mechanisms.

\section{Materials and methods}

\section{Experimental site and soil sampling}

This study was carried out in the central part of Madagascar. Hillsides are dominated by Ferralsols according to the FAO classification and are subjected to a hot rainy season from November to April and a a

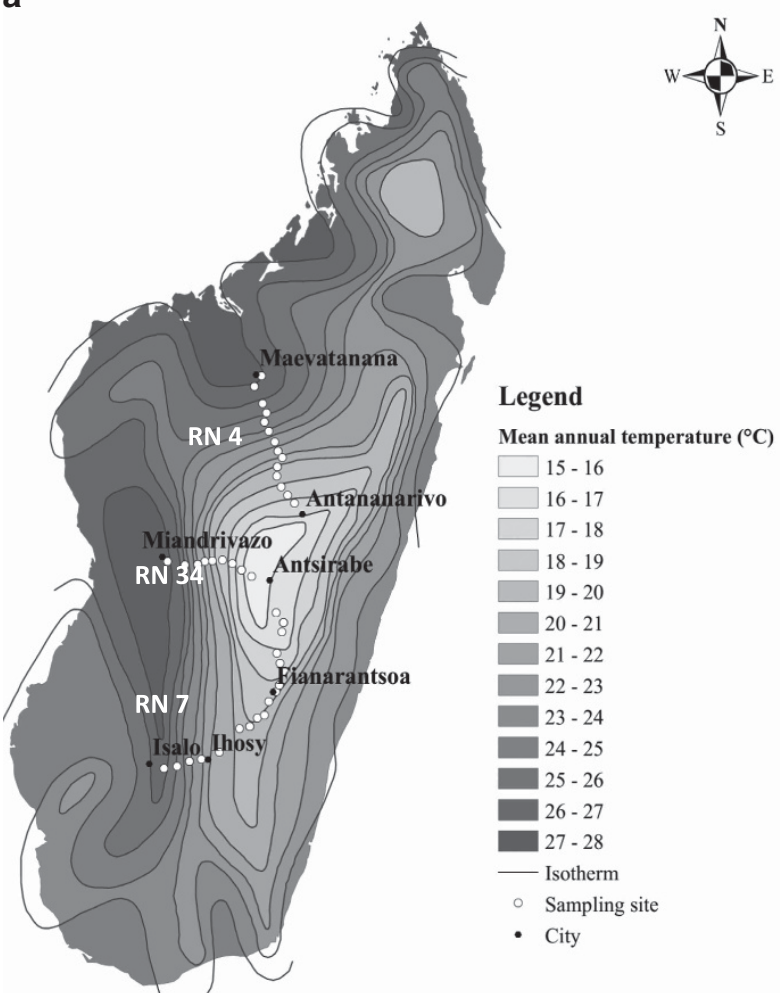

b

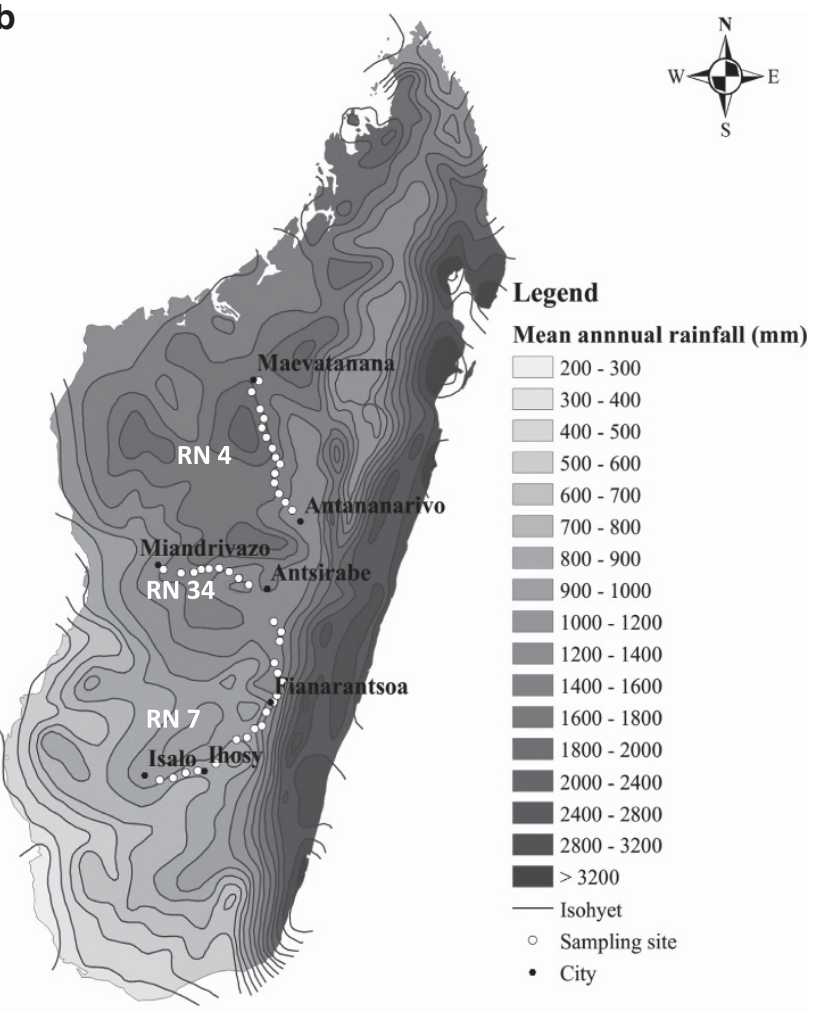

Figure 1 Map of the study region with isohyets. (a: average annual temperature; b: average annual precipitation) and locations of the 40 sampling sites. Climatic data were obtained from the WORLDCLIM database (Hijmans et al., 2005). 
cold dry season from May to October (Figure 1). In May 2014, soil samples from 41 plots were collected under similar vegetation (natural herbaceous savannas dominated by the grass Aristida sp., Poaceae). Plots were located along three national roads (Figure 1-RN4, RN34 and RN7), allowing effects of MAT and MAP to be distinguished.

The mean annual temperature and precipitation of the three climatic gradients ranged from 18.6 to $25.5^{\circ} \mathrm{C}$ and from 1359 to $1508 \mathrm{~mm}$ for RN34, from 17.7 to $26.8^{\circ} \mathrm{C}$ and from 1327 to $1817 \mathrm{~mm}$ for RN4, and from 16.4 to $22^{\circ} \mathrm{C}$ and from 779 to $1491 \mathrm{~mm}$ for RN7. The mean annual temperature and rainfall data were extracted from the WORLDCLIM database (Hijmans et al., 2005), obtained from 1950 to 2000, on the basis of the geographic coordinates of each sampling point. Unfortunately, no data were available at this scale for the following 14 years. Climate studies in Madagascar indicate that between 1961 and 2005, in the Highlands of Madagascar, MAT increased by $0.02{ }^{\circ} \mathrm{C}$ per year while MAP slightly decreased; this tendency is expected to increase during the next decades (Randriamarolaza, Meteo Madagascar, unpublished). In each plot, six soil cores, $0-10 \mathrm{~cm}$ depth and $1 \mathrm{~m}$ apart, were sampled using a metallic cylinder. One core was used to measure soil bulk density and other physicochemical parameters. The remaining 5 soil cores were pooled, sieved at $2 \mathrm{~mm}$, and coarse plant debris were removed. Composite samples were maintained at $4^{\circ} \mathrm{C}$ for no $>1$ week, prior to further fresh soil incubations and analyses.

\section{Soil characterization}

Different soil parameters, that is, amorphous aluminum and iron oxide contents and soil $\mathrm{pH}-\mathrm{H}_{2} \mathrm{O}$ in the 0-10 cm horizon were collected from the Madagascar soil database. All the other parameters were measured after our sampling in May 2014. Soil bulk density and water content were calculated by weighing fresh and oven-dried bulk soil cores. Particle size distribution was determined by the Robinson pipette method (Pansu and Gautheyrou, 2007). The effective cation exchange capacity (CEC) was determined by suspending soil in cobaltihexamine chloride solution (100 $\mathrm{mg} \mathrm{l}^{-1} ; 1: 10$ ratio) at soil $\mathrm{pH}$ and measured by flame spectrophotometry (Ciesielski et al., 1997). Total carbon (C) and nitrogen (N) contents were evaluated by dry combustion in a CHN analyzer (PerkinElmer Inc., Waltham, MA, USA).

Soil mineral contents (that is, kaolinite and gibbsite) were estimated by near infrared reflectance spectroscopy (NIRS), using the model developed by Ramaroson et al. (2017).

The nitrate and ammonium $\left(\mathrm{NO}_{3}\right.$ and $\left.\mathrm{NH}_{4}\right)$ contents, obtained after $\mathrm{KCl}$ extraction, were determined by colorimetry according to the Berthelot reaction $\left(\mathrm{NH}_{4}\right)$ and the Griess reaction $\left(\mathrm{NO}_{3}\right)$ (Mulvaney, 1986) using an automated continuous flow analyser $\operatorname{San}^{++}$(Skalar analytique, France). The total $\mathrm{P}$ content was determined using perchloric acid attack (Jackson, 1958). The available phosphorus (av $\mathrm{P})$ content and microbial biomass $\mathrm{P}$ (MBP) were measured using anion exchange resin after a fumigation-extraction method (Kouno et al., 1995) adapted from Amer et al. (1955).

\section{Molecular analyses of soil bacterial and fungal communities}

After field sampling, $50 \mathrm{~g}$ subsamples were maintained at $4{ }^{\circ} \mathrm{C}$, transported to France (Genosol platform, Dijon) and lyophilized for further molecular analyses. Microbial DNA was extracted from $2 \mathrm{~g}$ of lyophilized soil subsamples using the procedure described in (Plassart et al., 2012). Quantification of DNA extracted from soil was used to estimate the 'microbial molecular biomass' (MMB) in each sample, as it corresponds to the amount of DNA extracted from $1 \mathrm{~g}$ of soil (Marstorp et al., 2000; Widmer et al., 2006; Dequiedt et al., 2011). Quantitative real-time PCR was performed on extracted DNA to quantify $16 \mathrm{~S}$ and $18 \mathrm{~S}$ rDNA gene sequences (Lienhard et al., 2012; Plassart et al., 2012), which led to the estimation of the fungal to bacterial ratio (F:B). For microbial diversity and composition analyses, banks of $16 \mathrm{~S}$ and $18 \mathrm{~S}$ ribosomal sequences were prepared prior to pyrosequencing analyses as described in Maron et al. (2011). Pyrosequencing was carried out on a GS FLX Titanium (Roche 454 Sequencing System). Biocomputering analysis of the sequences was performed using the GnS-PIPE (Terrat et al., 2012), as described in detail in Tardy et al. (2015). In order to compare the data sets efficiently and avoid biased community comparisons, the sample reads were reduced by random selection closed to the lowest data sets (3000 reads for $16 \mathrm{~S}$ and $18 \mathrm{~S}-r R N A$ gene sequences respectively for each soil sample). The retained high-quality reads were used for taxonomy-based analysis using similarity approaches and dedicated reference databases from SILVA. Richness and diversity indices (number of OTUs, Evenness index) were determined at a dissimilarity threshold of $5 \%$.

DNA sequences were deposited in the European Nucleotide Archive, under the study accession number PRJEB19651.

Soil microcosm set-up and priming effect assessment To assess the potential capacity of microbial communities to mineralize soil and fresh organic matter at a similar temperature of $27^{\circ} \mathrm{C}$ (that is, regular incubation temperature for tropical soil-Bernard et al., 2012), fresh composite soil samples were used to fill 2 series of $150-\mathrm{ml}$ plasma flasks with $10 \mathrm{~g}$ of equivalent dry soil. The soil water content was adjusted to $70 \%$ of the saturation threshold using sterile deionized water. Both series were preincubated for 7 days in the dark. Then, one of the 
microcosm series was amended with $7 \%{ }^{13} \mathrm{C}$ - labeled wheat straw powder $(0.004 \mathrm{~g}$ straw per gram of dry weight soil) characterized by a C:N:P ratio of 108:4:1; the second series was not amended.

The microcosms of both series were then incubated (open, that is, unsealed) for 42 days. The soil water content was controlled throughout the incubation and adjusted with sterile deionized water when needed to prevent variation in soil moisture. Measurements of $\mathrm{CO}_{2}$ emissions (total $\mathrm{CO}_{2}$ and ${ }^{13} \mathrm{C}-\mathrm{CO}_{2}$ ) were performed on the 7th and 42nd day of the incubation, to correspond to 'early' and 'late' steps of FOM mineralization and PE. Prior to gas sampling, the microcosms were flushed with air to renew the atmosphere and were hermetically sealed for 3 days before measurements were conducted.

Total $\mathrm{CO}_{2}$ and ${ }^{13} \mathrm{C}-\mathrm{CO}_{2}$ measurements

The total atmospheric $\mathrm{CO}_{2}$ concentration was measured in all microcosms using a micro-CPG (CP-4900, Varian, Middelburg, The Netherlands). A 5-ml volume of the gaseous phase, of the straw-amended microcosms only, was sampled in Exatainer evacuated tubes (LABCO limited, UK) for further determination of carbon isotopic abundances using IRMS as described in Bernard et al. (2012).

$\mathrm{PE}$ was calculated as follows: $\mathrm{PE}=$ total measured $\mathrm{CO}_{2}$ of the straw-amended microcosm-straw- derived $\mathrm{CO}_{2}$ (calculated from the ${ }^{13} \mathrm{CO}_{2}$ atomic percentage, SM for straw mineralization)-total $\mathrm{CO}_{2}$ measured in the non-amended microcosm (BR for basal respiration).

\section{Statistics}

Pearson correlations between all variables were calculated using XLSTAT software (Addinsoft, Paris, France). Significance of correlations was tested by the Bartlett test. All variables correlating to at least one of the carbon mineralization activities (BR; SM; $\mathrm{PE})$, positively or negatively, at 7 or 42 days, and at a signification threshold of $1 \%$, were retained to build up a principal component analysis (PCA).

\section{Results}

Raw data obtained on each sampling plot from the analysis of all physicochemical and microbial parameters are presented in Supplementary Data set 1, with the principal descriptive statistics. The complete Pearson correlation matrix generated from Supplementary Data set 1 is presented in Supplementary Data set 2, while the PCA built on variables significantly $(P$-values $<0.01)$ correlated to basal respiration, straw mineralization or PE is shown in Figure 2.

Biplot ( F1 \& F2 axes: $52.71 \%$ )

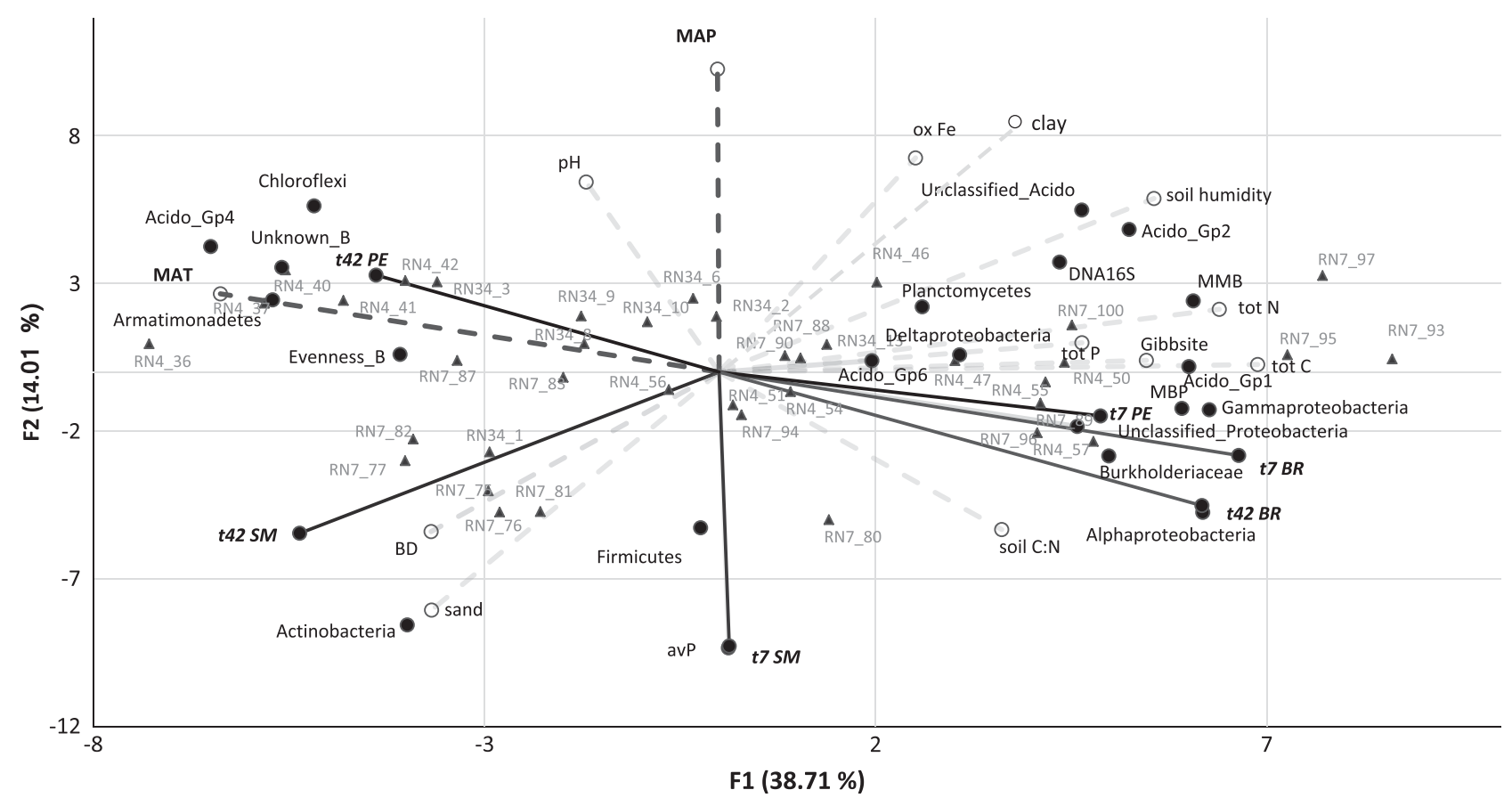

Figure 2 Biplot representation of the Principal Component Analysis (PCA) performed on the 40 biotic and abiotic variables measured on the 40 soils sampled. The correlation circle of variables was superimposed to the PCA plot. Triangles represent sampling plots; dashed gray lines represent soil abiotic variables; dashed black lines represent climatic variables; plain black circles represent biotic variables. Plain black lines represent carbon mineralization activities. Acido, Acidobacteria; avP, available phosphorus; _B, Bacteria; tot, total; BD, bulk density; BR, basal respiration; MAP, mean annual precipitation; MAT, mean annual temperature; MBP, microbial biomass phosphorus; MMB, microbial molecular biomass; SM, straw mineralization. 


\section{Soil physicochemical properties}

Soils were sampled at 60 to $1600 \mathrm{~m}$ a.s.l. and were mainly sandy clay loam or clay textured soils. Mean metal oxide contents $\mathrm{s}$ were $1.3 \mathrm{mg} \mathrm{g}^{-1}$ soil for aluminum and $1.6 \mathrm{mg} \mathrm{g}^{-1}$ soil for iron. Mean soil carbon content was about $2 \%$ with a C:N ratio of 16 , mean mineral nitrogen content was $6 \mathrm{mg} \mathrm{kg}^{-1}$ soil and mean available phosphorus was $0.6 \mathrm{mg} \mathrm{kg}^{-1}$. Mean bulk density was $1.3 \mathrm{~g} \mathrm{~cm}^{-3}$, mean $\mathrm{pH} 5.5$ and mean CEC $2.7 \mathrm{cmol} \mathrm{kg}^{-1}$ of soil. Correlations between soil, site and climate variables are described in Supplementary Data set 2. Higher altitudes were characterized by higher clay content, especially of gibbsite type, higher soil $\mathrm{C}$ and $\mathrm{N}$ contents and a higher $\mathrm{C}: \mathrm{N}$ ratio. By contrast, bulk density, $\mathrm{pH}$ and CEC were lower at these altitudes compared to lower altitudes-and warmer climates, as altitude was strongly negatively correlated to mean annual temperature (MAT). Some variables were correlated to mean annual precipitations (MAP), either positively, that is, clay content, $\mathrm{pH}$ and iron oxides, or negatively: sand content, soil C:N and available $\mathrm{P}$. The first axis of the PCA (Figure 2) represented more than $38 \%$ of the total variance and was driven by the MAT, while the second axis accounted for only $14 \%$ of the total variance and was mainly driven by the MAP.

\section{Abundance and diversity of bacterial and fungal communities}

The microbial communities from savanna Malagasy Ferralsols showed an $\mathrm{F}: \mathrm{B}$ ratio ranging from 0.02 to 0.21 (Supplementary Data set 1). The main bacterial phyla ( $>10 \%$ of total sequences each) were Proteobacteria, Planctomycetes, Acidobacteria, Actinobacteria and Chloroflexi and major fungal phyla were Ascomycota and Basidiomycota. Unknown sequences represented 16 and $6 \%$ of total bacterial and fungal sequences, respectively. MAT was positively correlated to bacterial evenness, Unknown bacteria, Actinobacteria, Chloroflexi, AcidobacteriaGP4 and Armatimonadetes (Figure 2, Supplementary Data set 2). Oppositely, microbial molecular biomass (MMB-that is, DNA extraction yield), microbial biomass phosphorus (MBP-giving also an idea of the physiological status as $\mathrm{P}$ enters in DNA and RNA molecules), the bacterial density assessed by the number of $16 \mathrm{~S}$ ribosomal genes (DNA $16 \mathrm{~S}$ ), Planctomycetes, all Proteobacteria subgroups and Acidobacteria GP-1,-2,-6, were negatively correlated to MAT. MAP was positively correlated only to Chloroflexi and negatively to Actinobacteria.

\section{C mineralization}

Considering all sampling sites and the whole incubation period, basal respiration ranged between 0.087 and $1.042 \mu \mathrm{g} C-\mathrm{CO}_{2}$ per g soil per $\mathrm{h}$. Straw mineralization ranged between 0.242 and $2.634 \mu \mathrm{g} C-\mathrm{CO}_{2}$ per g soil per $\mathrm{h}$. The PE ranged between -15 and $130 \%$ of basal respiration (Figure 3-Supplementary Data set 1).

Basal respiration did not change over time and was strongly and negatively linked to MAT (Table 1). Straw mineralization was strongly and negatively linked to MAP at 7 days and slightly positively correlated to MAT at 42 days. PE switched from being strongly and negatively correlated to MAT at 7 days, to being positively correlated to MAT at 42 days.

Basal respiration at both incubation dates was positively correlated to soil clay and gibbsite contents, $\mathrm{C}, \mathrm{N}$ and $\mathrm{P}$ content and C:N ratio (Table 2 - Supplementary Data set 2). Straw mineralization at 7 days was positively related to soil available $\mathrm{P}$ content and negatively related to $\mathrm{pH}$ and iron oxide content. A positive correlation was visible with mineral $\mathrm{N}$ but was not significant even at a $P$-value $<0.05$ (Supplementary Data set 2). At 42 days, straw mineralization was positively driven by bulk density and sand percentage and negatively by initial soil humidity, iron oxide and $\mathrm{C}$ and $\mathrm{N}$ contents. $\mathrm{PE}$ at 7 days was positively correlated to soil Gibbsite enrichment, as well as to soil $\mathrm{C}$ and $\mathrm{N}$ content and $\mathrm{C}$ : $\mathrm{N}$ ratio, while the opposite was observed at 42 days with less significant relationships. Soil microbial parameters correlated to one or more C mineralization activities were $\mathrm{MMB}, \mathrm{MBP}$, bacterial density (DNA 16 S), bacterial evenness (Evenness_B) and many bacterial Phyla or subphyla. Acidobacteria and Proteobacteria showed no strong relationship with respiration parameters at the phylum level, whereas certain lower phylogenetic levels did. Basal respiration was positively correlated to microbial and more precisely bacterial biomass, initial relative gene abundance of all Proteobacteria, and Subdivisions 1 and 2 of Acidobacteria (Gp1, Gp2). Straw mineralization was positively correlated to Firmicutes and Actinobacteria at 7 days and to Actinobacteria and Chloroflexi at 42 days. PE at 7 days was positively correlated to the same parameters as basal respiration and also to Planctomycetes and AcidobacteriaGP6. All these correlations were negative at 42 days and PE was then positively correlated to Unknown bacteria, Chloroflexi and Acidobacteria-GP4 only. In contrast to bacterial parameters, no fungal parameter was strongly correlated to any C mineralization activity.

\section{Discussion}

Stoichiometric decomposition vs nutrient mining Early PE intensity (7 days) was strongly and positively linked to basal respiration. Both also depended on microbial biomass, soil enrichment in organic matter and its quality informed by the soil $\mathrm{C}: \mathrm{N}$ ratio. According to the literature, soil basal respiration is mainly related to the decomposition of a high-quality SOM pool (high C:N ratio; Murphy et al., 2015). Our results suggest that $\mathrm{PE}$ generated at 7 days is a stimulation of this high-quality SOM 


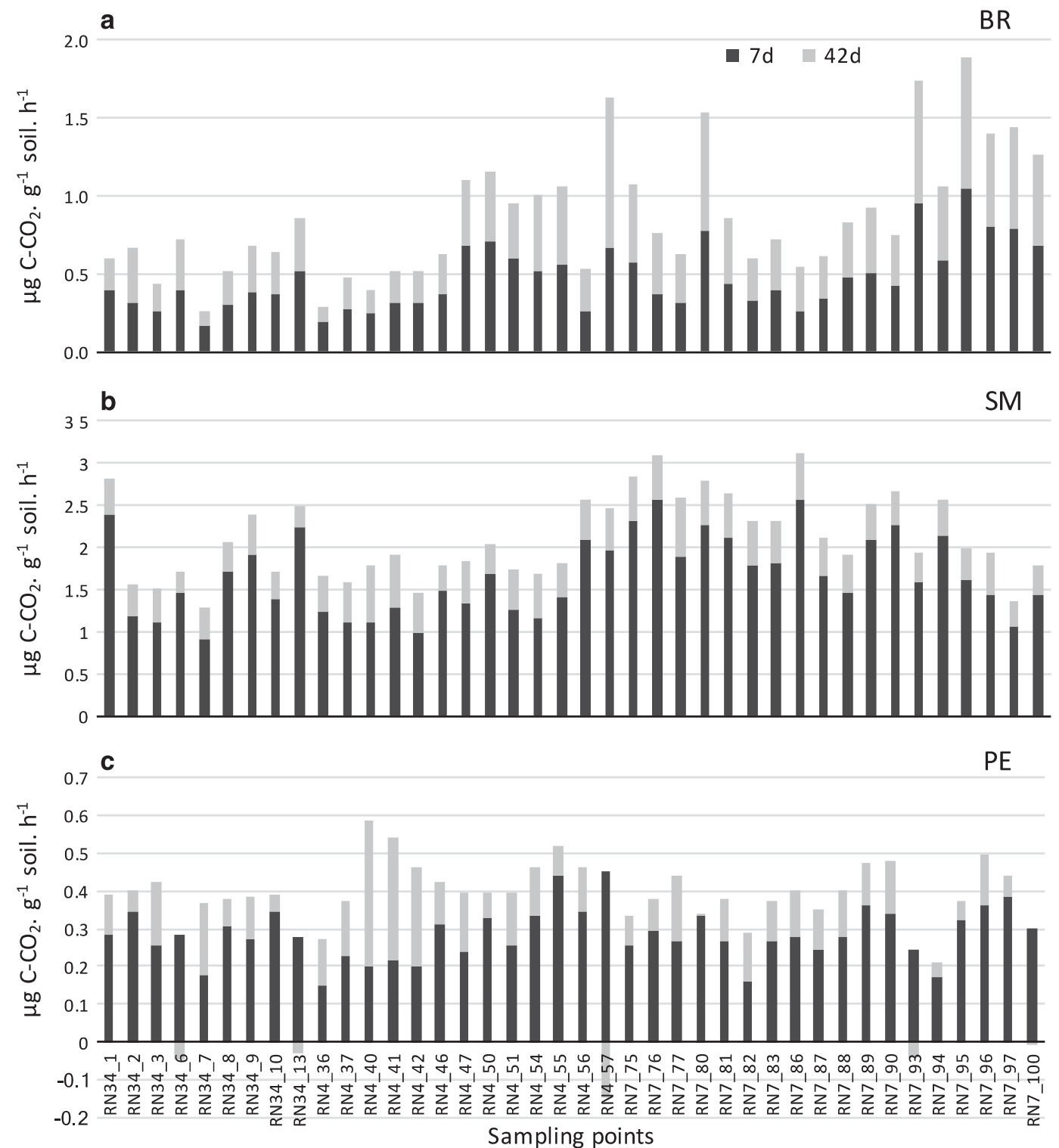

Figure 3 Cumulative histogram plot of (a) basal respiration, (b) straw mineralization and (c) PE at 7 and 42 days of incubation of the 41 sampled soils.

Table 1 Partial correlation matrix between climatic variables, and C mineralization activities registered at both incubation times (7 and 42 days)

\begin{tabular}{lcccrr}
\hline Variables & $7 d_{-} B R$ & $7 d_{-} S M$ & $7 d_{-} P E$ & $42 d_{-} B R$ & $42 d_{-} S M$ \\
\hline MAP & -0.142 & $-\mathbf{0 . 6 4 6}$ & -0.071 & -0.290 & -0.308 \\
MAT & $-\mathbf{0 . 7 0 4}$ & -0.242 & $-\mathbf{0 . 5 3 7}$ & $-\mathbf{0 . 6 2 5}$ & 0.322 \\
t7_BR & $\mathbf{1}$ & 0.084 & 0.371 & $\mathbf{0 . 8 8 3}$ & -0.242 \\
t7_SM & 0.084 & $\mathbf{1}$ & 0.126 & $\mathbf{0 . 1 8 2}$ & $\mathbf{0 . 4 5 8}$ \\
t7_PE & 0.371 & 0.126 & $\mathbf{0 . 5 3 8}$ & -0.093 \\
t42_BR & $\mathbf{0 . 8 8 3}$ & 0.182 & $\mathbf{0 . 5 3 8}$ & -0.104 & -0.359 \\
t42_SM & -0.242 & 0.093 & -0.269 & -0.104 & $-\mathbf{0 . 4 6 5}$ \\
t42_PE & $-\mathbf{0 . 4 8 3}$ & -0.357 & $\mathbf{- 0 . 4 6 5}$ & $\mathbf{0 . 6 3 5}$ & $\mathbf{0 . 6 3 5}$ \\
\hline
\end{tabular}

Abbreviations: BR, basal respiration; d, days; MAP, mean annual temperature; MAT, mean annual rainfall; PE, priming effect; SM, straw mineralization. Bold correlation coefficients represent $P$-values $<0.01$, and underlined correlation coefficients represent $P$-values $<0.05$. 
Table 2 Partial correlation matrix between the biotic and abiotic variables, retained to build the PCA (Figure 2), and C mineralization activities registered at both incubation times ( 7 and 42 days)

\begin{tabular}{|c|c|c|c|c|c|c|}
\hline Variables & $7 d \_B R$ & $7 d \_S M$ & $7 d \_P E$ & 42d_BR & 42d_SM & $42 d \_P E$ \\
\hline $\mathrm{BD}$ & -0.527 & 0.277 & -0.404 & -0.444 & 0.513 & 0.272 \\
\hline Sand & -0.334 & 0.309 & -0.133 & -0.188 & 0.441 & 0.085 \\
\hline Clay & 0.390 & -0.294 & 0.182 & 0.247 & -0.384 & -0.054 \\
\hline Gibbsite & 0.487 & -0.101 & 0.607 & 0.490 & -0.285 & -0.337 \\
\hline Soil humidity & 0.528 & -0.149 & 0.300 & 0.377 & -0.675 & -0.372 \\
\hline $\mathrm{pH}$ & -0.143 & -0.487 & -0.304 & -0.153 & -0.138 & 0.103 \\
\hline ox Fe & 0.050 & -0.325 & 0.260 & -0.012 & -0.426 & -0.019 \\
\hline Tot C & 0.821 & -0.101 & 0.486 & 0.694 & -0.339 & -0.326 \\
\hline Tot N & 0.750 & -0.142 & 0.436 & 0.620 & -0.397 & -0.300 \\
\hline Tot $\mathrm{P}$ & 0.423 & 0.049 & 0.254 & 0.392 & -0.300 & -0.280 \\
\hline Soil C:N & 0.447 & 0.158 & 0.332 & 0.430 & 0.062 & -0.175 \\
\hline avP & 0.281 & 0.425 & -0.055 & 0.359 & 0.329 & -0.175 \\
\hline MBP & 0.876 & -0.066 & 0.396 & 0.831 & -0.182 & -0.391 \\
\hline MMB & 0.757 & -0.143 & 0.406 & 0.695 & -0.405 & -0.438 \\
\hline DNA16s & 0.504 & -0.122 & 0.163 & 0.461 & -0.406 & -0.393 \\
\hline Evenness_B & -0.456 & 0.150 & -0.246 & -0.412 & -0.080 & -0.059 \\
\hline Planctomycetes & 0.173 & -0.075 & 0.527 & 0.198 & -0.236 & -0.190 \\
\hline Unknown_B & -0.747 & -0.142 & -0.673 & -0.758 & 0.243 & 0.542 \\
\hline Actinobacteria & -0.264 & 0.394 & -0.263 & -0.102 & 0.505 & 0.055 \\
\hline Chloroflexi & -0.672 & -0.399 & -0.457 & -0.688 & 0.385 & 0.732 \\
\hline Alpha-proteobacteria & 0.762 & 0.245 & 0.696 & 0.804 & -0.203 & -0.547 \\
\hline Acidobacteria_Gp1 & 0.678 & 0.052 & 0.304 & 0.506 & -0.465 & -0.415 \\
\hline Gamma-proteobacteria & 0.685 & 0.105 & 0.415 & 0.526 & -0.314 & -0.309 \\
\hline Delta-proteobacteria & 0.396 & -0.025 & 0.232 & 0.424 & -0.378 & -0.447 \\
\hline Burkholderiaceae & 0.685 & 0.174 & 0.230 & 0.618 & -0.217 & -0.431 \\
\hline Acidobacteria_Gp2 & 0.391 & -0.330 & 0.446 & 0.347 & -0.389 & -0.205 \\
\hline Acidobacteria_Gp4 & -0.594 & -0.309 & -0.471 & -0.527 & 0.210 & 0.356 \\
\hline Firmicutes & 0.036 & 0.549 & -0.072 & -0.008 & -0.116 & -0.273 \\
\hline Unclassified_Proteobacteria & 0.498 & 0.034 & 0.657 & 0.662 & -0.255 & -0.595 \\
\hline Armatimonadetes & -0.708 & -0.059 & -0.447 & -0.587 & 0.088 & 0.170 \\
\hline Acidobacteria_Gp6 & 0.080 & -0.022 & 0.511 & 0.304 & -0.108 & -0.346 \\
\hline Unclassified_Acidobacteria & 0.343 & -0.198 & 0.291 & 0.312 & -0.586 & -0.449 \\
\hline
\end{tabular}

Abbreviations: av, available; B, bacteria; BR, basal respiration; BD, bulk density; d, days; DNA 16 S, number of 16 S genes; Gibbsite, predicted by NIRS; MBP, microbial biomass phosphorus; MMB, molecular microbial biomass; ox Fe, iron oxide measured by oxalate extraction; SM, straw mineralization; Tot, total. Bold correlation coefficients represent $P$-values $<0.01$, and underlined correlation coefficients represent $P$-values $<0.05$.

mineralization probably due to the extra release of enzymes by wheat straw decomposers (Fontaine et al., 2003). In a study by Chen et al. (2014), mineral $\mathrm{N}$ positively drove the intensity of this process ('Stoichiometry theory'). In the present study, neither mineral $\mathrm{N}$ nor available $\mathrm{P}$ drove early PE. Available $\mathrm{P}$ and to a lesser extent mineral $\mathrm{N}$ positively drove the mineralization of wheat straw which induced PE, but $\mathrm{PE}$ intensity was not correlated to straw mineralization intensity. PE correlated strongly to soil gibbsite content. Oxide and hydroxide surfaces (mainly gibbsite in our soils) have been shown to sorb large amounts of dissolved organic matter (DOM), mainly through ligand exchange (Calvet et al., 2007). Therefore, in those Ferralsols, stoichiometric PE could have been limited by the low availability of organic nutrients associated to the mineral phase. During alkalinisation of soil solution following SM (Breemen et al., 1983), the neutralization of positive charges in variable-charge soils (Becquer et al., 2001) could decrease the sorption of DOM (Hunt et al., 2007), as well as those of organic and inorganic phosphate (Pavinato et al., 2010).

Late PE intensity (42 days) was inversely correlated to that generated at the earliest step, to basal respiration and to some soil parameters (SOM content, C:N and microbial biomass). Late PE appeared to be specific to a more stabilized SOM, and its intensity was positively linked to wheat straw mineralization. This suggests that late $\mathrm{PE}$ was generated by slow-growing microbes which cometabolized wheat straw and SOM, probably mining for nutrients (Fontaine et al., 2003; Blagodatskaya et al., 2014; Chen et al., 2014).

\section{Microbial actors of $C$ mineralization processes}

The F:B ratio measured in this study was low compared to other biomes (Fierer et al., 2009), indicating that the functioning of carbon-depleted Ferralsols under grass savannas is mainly driven by the bacterial- rather than by the fungal-energy channel of the soil food web (Wardle, 2005). Fungi tend to be better represented and more diverse in forested soils (Johnson and Wedin, 1997; Imberger and Chiu, 2001; Fierer et al., 2009).

The present study highlighted the specificity of various bacterial phylogenetic groups for the decomposition and mineralization of different types of organic matter. Wheat straw, the most easily- 
available form of organic matter entering the soil, appeared to be first mineralized by Firmicutes and Actinobacteria. Our results are in line with other studies that used a DNA-SIP direct approach (Bernard et al., 2012; Pascault et al., 2013). The Firmicutes are among the fastest-growing bacteria with 12 copies of the RNA operon in their genome (Klappenbach et al., 2000), but are also endowed with strong catabolic capacities like phytate hydrolyzation (Jorquera et al., 2008). Actinobacteria are known to have enzymatic activities able to depolymerize FOM, such as cellulolytic activities (de Boer et al., 2005). The late step of wheat straw mineralization still appeared related to the initial relative density of Actinobacterial genes, while Chloroflexi could also be involved. Chloroflexi are reported to have a very slow growth rate (Davis et al., 2011) and to prevail in nutrient poor soils (Janssen, 2006; Will et al., 2010; Fierer et al., 2012). Moorhead and Sinsabaugh (2006) have functionally classified microorganisms on the basis of the lability vs recalcitrance status of their respective growth substrates, with (1) opportunists feeding on small labile molecules, (2) decomposers breaking down polymerized vegetal tissues and (3) miners devoted to the humified stabilizing SOM. According to this terminology, Firmicutes and Actinobacteria could be qualified as FOM decomposers, and Chloroflexi as SOM miners.

Basal respiration was positively correlated to the initial relative density of all Proteobacteria subgroups, Planctomycetes and Acidobacteria GP1, 2 and 6. Among these phylogenetic groups, $\beta$ - and $\gamma$ Proteobacteria are overall known to be fast-growing copiotrophic organisms feeding on labile organic substrates, and can be qualified as opportunists (Klappenbach et al., 2000; Fierer et al., 2007; Eilers et al., 2010). $\gamma$-Proteobacteria were besides strongly linked to the soil gibbsite content, supposedly be associated to proteins and aminoacids (de Junet et al., 2013). Other subgroups of Proteobacteria, Planctomycetes and Acidobacteria GP1, 2 and 6 can be qualified as SOM decomposers as they are linked to the mineralization of high C:N SOM which characterizes poorly-evolved OM like decaying plant tissues. Most of them appeared to be responsible for the early PE. At the opposite, some phylogenetic groups appeared to be inversely correlated to basal respiration and therefore specific to a more stabilized SOM: Armatimonadetes, Acidobacteria-GP4, Chloroflexi and all the unknown Bacteria. Chloroflexi, Acidobacteria-GP4 and the unknown bacteria appeared to be positively linked to PE intensity at 42 days. Acidobacteria-GP4 sequences are known to correlate negatively with SOM and $\mathrm{N}$ (Foesel et al., 2014) and their only culturable species was isolated from a semiarid savanna soil in Namibia (Foesel et al., 2013). This species is able to grow on protochatechuate, an aromatic substrate, and on other complex molecules such as chitin and cellulose. As Chloroflexi and Acidobacteria-GP4 were also positively correlated to the late step of wheat straw mineralization, they can be considered as miners which use the energy of FOM to mine humified SOM for nutrients.

These results are based on correlations between $\mathrm{CO}_{2}$ release and gene relative densities in the pristine soil before incubation. We are aware that the addition of wheat straw probably initiated the growth of several populations, tending to change the biomass and the structure of the community during the incubation, which could have distorted our interpretation of results. However, we assume that such changes should be somewhat restricted. This postulate is based on several considerations. First, the wide majority of soil microbial populations are SOM miners and therefore slow-growing populations (Ranjard and Richaume, 2001). These populations are believed to contribute only to late decomposition of wheat straw (Blagodatskaya et al., 2014), when large increases in biomass are not expected. At this stage straw-derived energy is thought to be invested in cell maintenance and production of extracellular enzymes for SOM mining, rather than in proliferation. In addition, SOM miners, also described as K-strategists are characterized by low copy numbers of the ribosomal operon and thus do not have the cellular capacity to proliferate, even given high availability of labile substrates (Klappenbach et al., 2000). At the opposite, respective biomass of fast-growing microbial populations, like opportunists or some decomposers, should be severely controlled by protozoan grazers and nematodes in case of proliferation (Ekelund and Rønn, 1994; Griffiths, 1994; Bonkowski et al., 2000).

Climatic determinants of $C$ mineralization activities Climate may drive biomass, structure and composition of microbial communities indirectly by shaping some key soil properties, with consequences on C-cycling activities. MAT appeared to have a stronger impact on soil biotic and abiotic variables than MAP. MAP negatively controlled the early step of FOM mineralization mainly by its negative control on available $\mathrm{P}$, and positive control on $\mathrm{pH}$. As $\mathrm{P}$ is poorly available in Malagasy Ferralsols, it is not surprising that this nutrient could limit the first mineralization step of a carbon-rich compound. The negative correlation between available $\mathrm{P}$ content and MAP likely originates from the increasing $\mathrm{P}$ sorption by $\mathrm{Fe}$ and $\mathrm{Al}$ oxyhydroxides resulting from higher weathering rates and silica leaching (Schaefer et al., 2008). Also, the decomposition of fresh and complex organic matters is carried out by extracellular enzymes whose activities strongly depend positively or negatively on $\mathrm{pH}$, especially in Malagasy Ferralsols (Kedi et al., 2013). And pH in highly weathered soil tends also to increase to values close to the zero-point charge of $\mathrm{Fe}$ and $\mathrm{Al}$ 


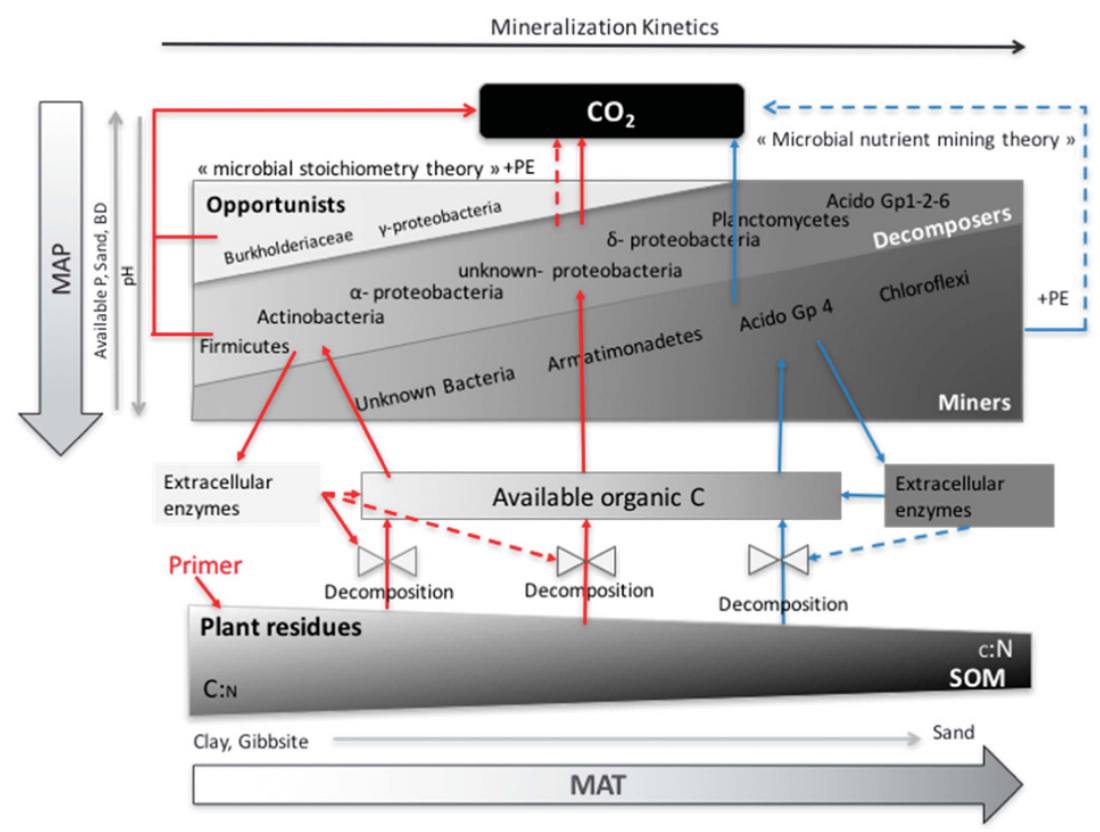

Figure 4 Conceptual scheme of the driving mechanisms of mineralization adapted from Chen et al. (2014). MAP represents mean annual precipitation, and MAT represents mean annual temperature. The microbial compartment is divided into 3 functional groups (Opportunists, Decomposers, Miners) and filled with associated phylogenetic groups. Light gray arrows represent influence of abiotic parameters; plain red arrows represent regular C fluxes transiting by the microbial Opportunist and Decomposer funnels; plain blue arrows represent regular $\mathrm{C}$ fluxes transiting by the microbial Miner funnel; dashed arrows represent the priming effect generated by microbial stoichiometric decomposition (in red) and microbial nutrient mining (in blue).

oxides (between 6 and 7; Schaefer et al., 2008). At the last incubation point, wheat straw mineralization was mainly controlled by soil texture, with higher mineralization rates in sandy soils as usually described in the literature (Saggar et al., 1996; Frøseth and Bleken, 2015).

The negative control of MAT on basal respiration and early PE appeared to be linked to the amount and quality of SOM. Temperature is known to drive positively the turnover of organic matter (Davidson and Janssens, 2006), while negatively affecting grass productivity in African savannas (Gao et al., 2016). Therefore, considering that MAT reduces FOM input while promoting its decomposition rate, the reduction of the high-quality SOM pool in warmer regions seems coherent. This was accompanied by the reduction of the density and physiological status (MBP) of microbial communities, and by the the reduction in size of the opportunist and decomposer guilds. Conversely, late PE, thought to follow the nutrient mining theory, increased with MAT because of this high-quality SOM depletion leading to the predominance of slow-growing miners. With less competition from opportunists and decomposers, miners should have more access to FOM energy for nutrient mining (Fontaine et al., 2003). Basal respiration and PE (early and late), when expressed as the ratio of $\mathrm{C}-\mathrm{CO}_{2}$ to total soil carbon or to microbial molecular biomass instead of to gram of soil, did all strongly and positively correlate to MAT (data not shown). Such a ratio of $\mathrm{CO}_{2}$ evolution to soil C or microbial biomass should be inversely related to the microbial Carbon Use Efficiency (that is, CUE: Growth/uptake-Geyer et al., 2016). And CUE has been shown to decrease with a change of microbial community composition from $\mathrm{r}$ to $\mathrm{K}$ strategist dominance (Blagodatskaya et al., 2014). Therefore, the positive correlation we observed between relative SOM mineralization (also PE, whatever the process implied) and MAT, should be just linked to the spatial variations of the microbial community composition.

If we transpose our observations in a context of global warming, the negative relationship between MAT and soil basal respiration could fit with the microbial thermal adaptation response observed in several warming studies (Luo et al., 2001; Rustad et al., 2001; Eliasson et al., 2005). Moreover, our study brings new elements with the suggestion that PE generated by stoichiometric decomposition should follow the same trend of attenuation as basal respiration. Conversely, PE generated by nutrient mining should increase, because of less competition between SOM decomposers and SOM miners for FOM. Therefore, the stabilizing SOM pool may become more sensitive to C-rich residue amendment in a context of long-term temperature elevation.

\section{Conclusion}

Our observations have been synthesized in a conceptual scheme (Figure 4), which is an adaptation of 
that presented by Chen et al. (2014). In Malagasy Ferralsols, the first steps of decomposition of a fresh plant residue seems to be controlled by edaphic parameters (available $\mathrm{P}, \mathrm{pH}$ and bulk density), driving the synthesis, the activity and the diffusion of extracellular enzymes, and by the population density of specialized decomposers (Firmicutes and Actinomycetes). All these biotic and abiotic factors seem to depend partly on annual precipitations and partly on soil texture, leading to the highest FOM mineralization in sandy soils submitted to hot and dry climates. In clayey soil submitted to a colder and more humid climate, the lower efficiency of FOM decomposition should foster the accumulation of high-quality SOM and support a denser community of microbial opportunists and decomposers. Mean annual temperature is also the main climatic driver of PE mechanisms through the selection of specialized populations (high-quality SOM decomposers under colder climates and co-metabolizer miners under warmer climates). Therefore, colder sites, richer in high-quality SOM, promote a PE generated by the 'stoichiometry theory' mechanism while warmer sites promote a PE generated by the 'nutrient mining theory'.

\section{Conflict of Interest}

The authors declare no conflict of interest.

\section{Acknowledgements}

The present study was funded by the French Foundation for Research on Biodiversity (FRB- AAP-SCEN-2013 II - CAMMiSolE project). The first author was awarded with a 5-month mobility research grant from Madagascar to France, funded by the Agropolis Foundation (AAP Open Science- CARIM project). We would like to thank Modeste Rakotondramanana (IRD) and Fidy Raharison (LRI) for their help with field sampling and Marie-Paule Razafimanantsoa (LRI) for her coaching during laboratory analyses.

\section{References}

Amer F, Bouldin DR, Black CA, Duke FR. (1955). Characterization of soil phosphorus by anion exchange resin adsorption and P32-equilibration. Plant Soil 6: 391-408.

Becquer T, Pétard J, Duwig C, Bourdon E, Moreau R, Herbillon AJ. (2001). Mineralogical, chemical and charge properties of Geric Ferralsols from New Caledonia. Geoderma 103: 291-306.

Bernard L, Chapuis-Lardy L, Razafimbelo T, Razafindrakoto M, Pablo A-L, Legname E et al. (2012). Endogeic earthworms shape bacterial functional communities and affect organic matter mineralization in a tropical soil. ISME J 6: 213-222.

Bernard L, Maron PA, Mougel C, Nowak V, Lévêque J, Marol C et al. (2009). Contamination of soil by copper affects the dynamics, diversity, and activity of soil bacterial communities involved in wheat decomposition and carbon storage. Appl Environ Microbiol 75: 7565-7569.

Bernard L, Mougel C, Maron P-A, Nowak V, Lévêque J, Henault C et al. (2007). Dynamics and identification of soil microbial populations actively assimilating carbon from 13C-labelled wheat residue as estimated by DNAand RNA-SIP techniques. Environ Microbiol 9: 752-764.

Bingeman CW, Varner JE, Martin WP. (1953). The effect of the addition of organic materials on the decomposition of an organic soil. Soil Sci Soc Am J 17: 34-38.

Blagodatskaya E, Khomyakov N, Myachina O, Bogomolova I, Blagodatsky S, Kuzyakov Y. (2014). Microbial interactions affect sources of priming induced by cellulose. Soil Biol Biochem 74: 39-49.

Bonkowski M, Griffiths BS, Scrimgeour C. (2000). Substrate heterogeneity and microfauna in soil organic 'hotspots' as determinants of nitrogen capture and growth of rye-grass. Appl Soil Ecol 14: 37-53.

Calvet R, Barriuso E, Dubus IG. (2007). Application of two surface complexation models to the adsorption of weak organic acids by soil: an additive approach. Eur J Soil Science 58: 609-624.

Chen R, Senbayram M, Blagodatsky S, Myachina O, Dittert K, Lin X et al. (2014). Soil C and N availability determine the priming effect: microbial $\mathrm{N}$ mining and stoichiometric decomposition theories. Glob Change Biol 20: 2356-2367.

Ciesielski H, Sterckeman T, Santerne M, Willery JP. (1997). Determination of cation exchange capacity and exchangeable cations in soils by means of cobalt hexamine trichloride. Effects of experimental conditions. Agronomie 17: 1-7.

Davidson EA, Janssens IA. (2006). Temperature sensitivity of soil carbon decomposition and feedbacks to climate change. Nature 440: 165-173.

Davis KER, Sangwan P, Janssen PH. (2011). Acidobacteria, Rubrobacteridae and Chloroflexi are abundant among very slow-growing and mini-colony-forming soil bacteria. Environ Microbiol 13: 798-805.

de Boer W, Folman LB, Summerbell RC, Boddy L. (2005). Living in a fungal world: impact of fungi on soil bacterial niche development. Fems Microbiol Rev 29: 795-811.

de Junet A, Basile-Doelsch I, Borschneck D, Masion A, Legros S, Christine Marole C et al. (2013). Characterisation of organic matter from organo-mineral complexes in an Andosol from Reunion Island. J Anal Appl Pyrolysis 99: 92-100.

Dequiedt S, Saby NPA, Lelievre M, Jolivet C, Thioulouse J, Toutain B et al. (2011). Biogeographical patterns of soil molecular microbial biomass as influenced by soil characteristics and management. Glob Ecol Biogeogr 20: $641-652$.

Derrien D, Plain C, Courty P-E, Gelhaye L, MoerdijkPoortvliet TCW, Thomas F et al. (2014). Does the addition of labile substrate destabilise old soil organic matter? Soil Biol Biochem 76: 149-160.

Eilers KG, Lauber CL, Knight R, Fierer N. (2010). Shifts in bacterial community structure associated with inputs of low molecular weight carbon compounds to soil. Soil Biol Biochem 42: 896-903.

Ekelund F, Rønn R. (1994). Notes on protozoa in agricultural soil with emphasis on heterotrophic 
flagellates and naked amoebae and their ecology. FEMS Microbiol Rev 15: 321-353.

Eliasson PE, McMurtrie RE, Pepper DA, Strömgren M, Linder S, Ågren GI. (2005). The response of heterotrophic CO2 flux to soil warming. Glob Change Biol 11: 167-181.

Fierer N, Bradford MA, Jackson RB. (2007). Toward an ecological classification of soil bacteria. Ecology 88: 1354-1364.

Fierer N, Lauber CL, Ramirez KS, Zaneveld J, Bradford MA, Knight R. (2012). Comparative metagenomic, phylogenetic and physiological analyses of soil microbial communities across nitrogen gradients. ISME $J$ 6: 1007-1017.

Fierer N, Strickland MS, Liptzin D, Bradford MA, Cleveland CC. (2009). Global patterns in belowground communities. Ecol Lett 12: 1238-1249.

Foesel BU, Nägele V, Naether A, Wüst PK, Weinert J, Bonkowski M et al. (2014). Determinants of Acidobacteria activity inferred from the relative abundances of $16 \mathrm{~S}$ rRNA transcripts in German grassland and forest soils. Environ Microbiol 16: 658-675.

Foesel BU, Rohde M, Overmann J. (2013). Blastocatella fastidiosa gen. nov., sp. nov., isolated from semiarid savanna soil - The first described species of Acidobacteria subdivision 4. Syst Appl Microbiol 36: 82-89.

Fontaine S, Mariotti A, Abbadie L. (2003). The priming effect of organic matter: a question of microbial competition? Soil Biol Biochem 35: 837-843.

Frøseth RB, Bleken MA. (2015). Effect of low temperature and soil type on the decomposition rate of soil organic carbon and clover leaves, and related priming effect. Soil Biol Biochem 80: 156-166.

Gao Q, Schwartz MW, Zhu W, Wan Y, Qin X, Ma X et al. (2016). Changes in Global Grassland Productivity during 1982 to 2011 Attributable to Climatic Factors. Remote Sens 8: 384.

Geyer KM, Kyker-Snowman E, Grandy AS, Frey SD. (2016). Microbial carbon use efficiency: accounting for population, community, and ecosystem-scale controls over the fate of metabolized organic matter. Biogeochem 127: 173-188.

Griffiths BS. (1994). Microbial-feeding nematodes and protozoa in soil: Their effects on microbial activity and nitrogen mineralization in decomposition hotspots and the rhizosphere. Plant Soil 164: 25-33.

Heimann M, Reichstein M. (2008). Terrestrial ecosystem carbon dynamics and climate feedbacks. Nature 451: 289-292.

Hijmans RJ, Cameron SE, Parra JL, Jones PG, Jarvis A. (2005). Very high resolution interpolated climate surfaces for global land areas. Int $J$ Climatol 25: 1965-1978.

Hunt JF, Ohno T, He Z, Honeycutt CW, Dail CB. (2007). Inhibition of phosphorus sorption to goethite, gibbsite, and kaolin by fresh and decomposed organic matter. Biol Fertil Soils 44: 277-288.

Imberger KT, Chiu C-Y. (2001). Spatial changes of soil fungal and bacterial biomass from a sub-alpine coniferous forest to grassland in a humid, subtropical region. Biol Fertil Soils 33: 105-110.

Jackson ML. (1958). Soil Chemical Analysis. Prentice Hall Inc: Englewood Cliffs, NJ, USA.

Janssen PH. (2006). Identifying the dominant soil bacterial taxa in libraries of $16 \mathrm{~S}$ rRNA and $16 \mathrm{~S}$ rRNA genes. Appl Environ Microbiol 72: 1719-1728.
Johnson NC, Wedin DA. (1997). Soil carbon, nutrients, and mycorrhizae during conversion of dry tropical forest to grassland. Ecol Appl 7: 171-182.

Jorquera MA, Hernández MT, Rengel Z, Marschner P, Mora M, de la L. (2008). Isolation of culturable phosphobacteria with both phytate-mineralization and phosphate-solubilization activity from the rhizosphere of plants grown in a volcanic soil. Biol Fertil Soils 44: 1025-1034.

Kedi B, Abadie J, Sei J, Quiquampoix H, Staunton S. (2013). Diversity of adsorption affinity and catalytic activity of fungal phosphatases adsorbed on some tropical soils. Soil Biol Biochem 56: 13-20.

Klappenbach JA, Dunbar JM, Schmidt TM. (2000). rRNA Operon Copy Number Reflects Ecological Strategies of Bacteria. Appl Environ Microbiol 66: 1328-1333.

Kouno K, Tuchiya Y, Ando T. (1995). Measurement of soil microbial biomass phosphorus by an anionexchange membrane method. Soil Biol Biochem 27: 1353-1357.

Kuzyakov Y, Friedel J, Stahr K. (2000). Review of mechanisms and quantification of priming effects. Soil Biol Biochem 32: 1485-1498.

Lienhard P, Tivet F, Chabanne A, Dequiedt S, Lelièvre M, Sayphoummie S et al. (2012). No-till and cover crops shift soil microbial abundance and diversity in Laos tropical grasslands. Agron Sustain Dev 33: 375-384.

Luo Y, Wan S, Hui D, Wallace LL. (2001). Acclimatization of soil respiration to warming in a tall grass prairie. Nature 413: 622-625.

Maron P-A, Mougel C, Ranjard L. (2011). Soil microbial diversity: Methodological strategy, spatial overview and functional interest. $C R$ Biol 334: 403-411.

Marstorp H, Guan X, Gong P. (2000). Relationship between dsDNA, chloroform labile $\mathrm{C}$ and ergosterol in soils of different organic matter contents and pH. Soil Biol Biochem 32: 879-882.

Moorhead DL, Sinsabaugh RL. (2006). A theoretical model of litter decay and microbial interaction. Ecol Monogr 76: 151-174.

Mulvaney ML. (1986). Nitrogen-Inorganic forms. In: Klute A (ed.) Methods of Soil Analysis Part 3. Chemical Methods. American Society of Agronomy: Madison, WI, USA, p 1130.

Murphy CJ, Baggs EM, Morley N, Wall DP, Paterson E. (2015). Rhizosphere priming can promote mobilisation of N-rich compounds from soil organic matter. Soil Biol Biochem 81: 236-243.

Neelin JD, Münnich M, Su H, Meyerson JE, Holloway CE. (2006). Tropical drying trends in global warming models and observations. PNAS 103: 6110-6115.

Pansu M, Gautheyrou J. (2007). Handbook of Soil Analysis: Mineralogical, Organic and Inorganic Methods. Springer Science \& Business Media: Berlin, Heidelberg, The Netherlands.

Pascault N, Ranjard L, Kaisermann A, Bachar D, Christen R, Terrat S et al. (2013). Stimulation of different functional groups of bacteria by various plant residues as a driver of soil priming effect. Ecosystems 16: 810-822.

Pavinato PS, Dao TH, Rosolem CA. (2010). Tillage and phosphorus management effects on enzyme-labile bioactive phosphorus availability in Cerrado Oxisols. Geoderma 156: 207-215.

Plassart P, Terrat S, Thomson B, Griffiths R, Dequiedt S, Lelievre $\mathrm{M}$ et al. (2012). Evaluation of the ISO standard 
11063 DNA extraction procedure for assessing soil microbial abundance and community structure. PLoS One 7: e44279.

Ramarosona VH, Becquer T, Sá SO, Razafimahatratra H, Larvy Delarivière J, Blavet D et al. (2017). Mineralogical analysis of ferralitic soils in Madagascar using NIR spectroscopy. Catena. Available at: http://dx.doi. org/10.1016/j.catena.2017.07.016.

Ranjard L, Richaume A. (2001). Quantitative and qualitative microscale distribution of bacteria in soil. Res Microbiol 152: 707-716.

Rustad L, Campbell J, Marion G, Norby R, Mitchell M, Hartley A et al. (2001). A meta-analysis of the response of soil respiration, net nitrogen mineralization, and aboveground plant growth to experimental ecosystem warming. Oecologia 126: 543-562.

Saggar S, Parshotam A, Sparling GP, Feltham CW, Hart PBS. (1996). 14C-labelled ryegrass turnover and residence times in soils varying in clay content and mineralogy. Soil Biol Biochem 28: 1677-1686.

Schaefer CEGR, Fabris JD, Ker JC. (2008). Minerals in the clay fraction of Brazilian Latosols (Oxisols): a review. Clay Miner 43: 137-154.

Tardy V, Spor A, Mathieu O, Lévèque J, Terrat S, Plassart P et al. (2015). Shifts in microbial diversity through land use intensity as drivers of carbon mineralization in soil. Soil Biol Biochem 90: 204-213.

Terrat S, Christen R, Dequiedt S, Lelièvre M, Nowak V, Regnier $\mathrm{T}$ et al. (2012). Molecular biomass and MetaTaxogenomic assessment of soil microbial communities as influenced by soil DNA extraction procedure. Microb Biotechnol 5: 135-141.

van Breemen N, Mulder J, Driscoll CT. (1983). Acidification and alkalinization of soils. Plant Soil 75: 283-308.

Wardle DA. (2005). How plant communities influence decomposer communities. In: Bardgett R, Usher $\mathrm{M}$, Hopkins D (eds.) Biological Diversity and Function in Soils (Ecological Reviews). Cambridge University Press: Cambridge, UK, pp. 119-138.

Widmer F, Rasche F, Hartmann M, Fliessbach A. (2006). Community structures and substrate utilization of bacteria in soils from organic and conventional farming systems of the DOK long-term field experiment. Appl Soil Ecol 33: 294-307.

Will C, Thürmer A, Wollherr A, Nacke H, Herold N, Schrumpf $\mathrm{M}$ et al. (2010). Horizon-specific bacterial community composition of german grassland soils, as revealed by pyrosequencing-based analysis of $16 \mathrm{~S}$ rRNA genes. Appl Environ Microbiol 76: 6751-6759.

Supplementary Information accompanies this paper on The ISME Journal website (http://www.nature.com/ismej) 